\title{
OD PRZESTRZENI DO TRANSMIGRACJI. TOŻSAMOŚĆ NARODOWA W ZWIERCIADLE KULTURY ARTYSTYCZNEJ \\ NA PRZYKŁADZIE TWÓRCZOŚCI KOLEKTYWU NEUE SLOWENISCHE KUNST
}

dea zjednoczonej Europy jest tematem powracającym przy okazji dyskusji o kondycji współczesności. Towarzyszy jej słynna, choć sporo młodsza, bo licząca sobie dwie dekady, teza Richarda O'Briena o „końcu geografii”, czyli utracie uprzywilejowanej pozycji przez kategorię przestrzeni. Funkcjonowanie w nieustannym ruchu związane jest ze zjawiskiem globalizacji i wzmożonym wpływem mediów umożliwiającym ogólnoświatowy przepływ idei, informacji, obrazu. W rezultacie ludzka aktywność odbywa się niejako na dwóch poziomach, w dwóch środowiskach jednocześnie: fizycznym oraz kształtowanym i przekazywanym przez technologie. ${ }^{1}$

Nie ulega jednak wątpliwości, iż poszczególne kraje europejskie charakteryzują się różnej długości stażem posiadania własnej państwowości. Obserwuje się więc dwie przeciwstawne postawy: z jednej strony istnieje ogólna tendencja do integracji ponad narodami, z drugiej natomiast mamy do czynienia z koncentracją na własnej historii, co może być przejawem nie dość solidnie ugruntowanej tożsamości narodowej. Z taką sytuacją można spotkać się szczególnie w przypadku tzw. małych narodów, które państwowością, na powrót odzyskaną bądź otrzymaną po raz pierwszy, cieszą się od niedawna.

Przestrzenna dowolność, charakteryzująca się ruchem o trudnym do przewidzenia kierunku, definiowana jest przez Martę Bucholc jako transmigracja, pojęcie zastosowane tu jako metafora współczesnego funkcjonowania w świecie.

Mgr Joanna SZCZEPANIK jest kulturoznawcą: przygotowuje rozprawę doktorską w Szkole Wyższej Psychologii Społecznej w Warszawie

i kieruje projektem badawczym w ramach Narodowego Centrum Nauki. joszte@hotmail.com

1 W.J. Burszta, Różnorodność i tożsamość. Antropologia jako kulturowa refleksyjność, Poznań 2004, s. 140. 
„Artysta bardziej niż ktokolwiek inny ucieleśnia charakterystyczne rysy sylwetki transmigranta. Jego tożsamość powstaje w ruchu w drodze aktywnego gromadzenia doświadczeń, wybieranych przez niego, wzmacnianych i generowanych - by wypowiedzieć w swojej ekspresji artystycznej zagmatwaną prawdę o wszystkich zasobach, których użył, aby być sobą takim, jakim jest w akcie tworzenia. To, co dla innych ruchliwych postaci naszych czasów (...) jest instytucjonalną koniecznością (...), dla artysty jest sensem jego twórczej aktywności. (...) Artysta chwyta intuicyjnie to, co kluczowe w egzystencji otaczającego go społeczeństwa, a mianowicie nową zasadę kreowania tożsamości. (...) Twórca stał się ucieleśnieniem duchowej tendencji współczesności, która polega na kształtowaniu indywidualnej tożsamości przez ruch fizyczny i społeczny"2.

Być może więc warto przyjrzeć się zagadnieniu współczesnej tożsamości narodowej przez pryzmat twórczości artystycznej pochodzącej z powstałych przed zaledwie dwiema dekadami państw europejskich. Jaki wpływ na tę aktywność mają zachodzące we współczesności zmiany? W którym kierunku ewoluują ich działania? Czy rzeczywiście widoczne jest w nich owo rozmycie, upłynnienie w przestrzeni, przypisywane procesowi przejścia od lokalności do globalności?

Niniejszy artykuł jest propozycją zwrócenia uwagi na działalność kolektywu artystycznego Neue Slowenische Kunst, który powstał w Słowenii w latach 80. XX wieku. Tożsamość artystyczna tej grupy została zbudowana na wyraźnym odniesieniu do charakteru narodowego na kilka lat przed powstaniem niepodległego państwa. Aktywność kolektywu przez niespełna trzy dekady stanowiła swoisty komentarz do zjawisk zachodzących zarówno na terenie dzisiejszej Słowenii, jak i poza nią.

Skrótowa analiza historyczna, przy jednoczesnym zaakcentowaniu aspektu kulturalnego rozwoju państwa słoweńskiego, pozwoli na możliwie całościowe ujęcie omawianego zagadnienia. Warto zaznaczyć, iż prezentowana grupa artystyczna, choć najbardziej reprezentatywna dla sztuki słoweńskiej poza granicami kraju, nie jest i nie była oczywiście jedynym podmiotem twórczym na jego obszarze, podobnie jak nie jest inicjatorem mody, prądu czy nurtu. Kolektyw ten jest koncepcją autorską, która nie znalazła naśladowców, z pominięciem tych, którzy zechcieli wziąć aktywny udział w jej tworzeniu i zdecydowali się stać częścią projektu.

\section{HISTORIA}

Przed dwoma laty w oddziale Muzeum Miejskiego Lublańskiego Zamku zainaugurowano ekspozycję zatytułowaną "Słoweńska historia”. Jej koncepcja wyraźnie pokazuje, iż choć państwo słoweńskie liczy sobie ledwie dwie dekady to słoweńskość - ponad tysiąc. Według planów autorstwa Jože Plečnika z lat 20. XX wieku, wybitnego Słoweńca i architekta praskich Hradczan, górująca nad Lublaną średniowieczna budowla miała stać się narodową Akropolis, sercem kraju i fizycznym przejawem wyobrażonej wspólnoty³. Ideę tę przywołał w niedawnej publikacji także Aleš Erjavec, przypominając, iż

„,na początku XX wieku jeden z największych intelektualistów słoweńskich, Josip Vidmar, propagowat ideę przewodnictwa tego niewielkiego kraju nie w sferze gospodarki czy polityki, lecz kultury i sztuki. Z jego marzeń narodziła się wizja «słoweńskich Aten» - stołeczna Lublana miała zasłynąć z kultury na cały świat niczym Ateny lub Florencja" ${ }^{4}$.

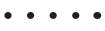

2 M. Bucholc, Tożsamość transmigranta, „Herito” nr 2 (1/2011), s. 76.

3 Ł. Galusek, Multimedialna Akropolis, "Herito" nr 1/2010, s. 118.

4 A. Erjavec, Neue Slowenische Kunst - Nowa Sztuka Stoweńska, [w:] Ausstelung Laibach Kunst Rekapitulacja/Recapitulation 2009, Katalog wystawy Łódź 2009, s. 104. 
Choć od momentu stworzenia planów architektonicznych Plečnika i idei Vidmara, Słoweńcy musieli poczekać jeszcze kilkadziesiąt lat na własną państwowość, ostatecznie kraj ten, usytuowany na etnojęzykowym pograniczu germańskim, romańskim, słowiańskim i ugrofińskim, doczekał się niepodległego terytorium.

Miroslav Hroch zwraca uwagę, iż tożsamość słoweńska wytworzyła, pokonując kolejne fazy: zjednoczenia się patriotycznej inteligencji studiującej język i kulturę grupy, uważanej za potencjalny naród, a następnie przekonania członków tej grupy do przyjęcia nowej, narodowej tożsamości. Sukces tych poczynań pozwolit przejść do etapu agitacji narodowej i fazy ruchu masowego będącego dowodem pomyślnego zaszczepienia procesu narodotwórczego 5 .

Słoweńcy stanowili jedną z rozproszonych wspólnot etnicznych żyjących na terenie monarchii habsburskiej i choć ludność zamieszkująca ten obszar zmuszona była utożsamić się z narodem i językiem niemieckim, nie udało się całkowicie osłabić jej świadomości regionalnej.

Okres reformacji przynióst pierwszą książkę w języku słoweńskim, Catechismus in der windischen Sprach (wydaną pod niemieckim tytułem w 1551 roku). Jej autora, Primoža Trubara, uznaje się za twórce podstaw słoweńskiego języka literackiego. Mimo iż reformacja na terenie Słowenii obecna była krótko, stanowiła pierwszy moment obudzenia się świadomości narodowej.

Choć trudno w tym skrótowym rysie znaleźć miejsce, by wymienić wszystkie ważne dla rozwoju słoweńskiej tożsamości osobistości, warto wspomnieć o Janezu Vajkardzie Valvasorze, szlachcicu żyjącym w epoce baroku, z pochodzenia Włochu, z języka Niemcu, a z poczucia patriotycznego Kraińcu, który przemierzając przestrzenie Europy i Afryki Północnej, nie tylko odkrył, iż poza terenami monarchii habsburskiej, Księstwo Krainy jest zupełnie nieznane, lecz także dostrzegł jego odrębność geograficzną i kulturową i resztę życia poświęcit studiom nad jej ukształtowaniem i przyrodą.

Stworzenie dojrzałego języka narodowego stało się podstawowym zadaniem w okresie oświecenia, kiedy stał się on symbolem odrębności słoweńskiej i świadectwem dojrzałości narodowej. Rozwojowi koncepcji własnej państwowości sprzyjały także czynniki zewnętrzne, takie jak zniesienie systemu feudalnego, większa tolerancja religijna, rewolucja francuska czy wojny napoleońskie. Charakterystycznym dla Słoweńców przejawem walki o zjednoczenie były „tabory ludu” organizowane w latach 1868-71. W tych demonstracjach jedności popularyzujących ideę zjednoczenia Słowenii uczestniczyły tysiące ludzi. W tym czasie także odbył się kongres Słowian Południowych, uznany przez polityka i duchownego chorwackiego, Josipa Juraja Strossmayera, za narodziny koncepcji jugostowiańskiej.

Owocem aktywnej industrializacji II połowy XIX wieku było powstanie organizacji robotniczych, między innymi w Lublanie i Trieście. W tym miejscu warto odnotować istnienie ważnego ośrodka strajków górniczych w Trbovlje, w którym ponad sto lat później zawiązała się grupa Laibach, główny pomystodawca kolektywu artystycznego Neue Slowenische Kunst.

Wraz z końcem I wojny światowej i upadkiem Austro-Węgier powróciła idea połączenia Słowian Południowych. Choć Słowenia w nowo powstałym państwie, Królestwie Serbów, Chorwatów i Słoweńców, stała się niewielką prowincją, charakteryzowała się dużą niezależnością kulturową oraz najszybszym tempem rozwoju gospodarczego. Początkowy entuzjazm wywołany urzeczywistnieniem idei jugosłowiańskiej, przejawiający się w poprawie stanu oświaty, wprowadzeniu języków narodowych oraz ożywieniu życia nauko-

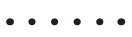

5 M. Hroch, Małe narody Europy, tłum. G. Pańko, Wrocław 2003, s. 9. 
wego, wkrótce zanikł w obliczu przybierających na sile konfliktów wewnętrznych, a szczególnie serbskiej polityki centralizacyjnej.

Po II wojnie światowej państwo Słowian zostało przekształcone w Federację Jugosłowiańską złożoną z sześciu republik. Słowenia ze stolicą w Lublanie zdołała utrzymać względną autonomię kulturową, choć pozostawała politycznie związana z resztą Jugosławii ${ }^{6}$. Mimo iż był to kraj socjalistyczny z jedną rządzącą partią i niekwestionowanym, autorytarnym przywódcą komunistycznym, nie został wciągnięty na listę krajów-satelitów Związku Socjalistycznych Republik Radzieckich. Jugosławia charakteryzowała się najwyższą spośród wszystkich krajów bloku socjalistycznego stopą życiową i najwyższym stopniem „wolności” na poziomie jednostki. Według zapisu konstytucji z 1946 roku, narody wchodzące w skład federacji posiadały prawo do samostanowienia, nie wyłączając prawa do separacji. Słoweńcy szczególnie stanowczo przestrzegali jego respektowania i stając w obronie swoich przywilejów i wolności politycznej, często narażani byli na zarzut nacjonalizmu. Ów zapis konstytucyjny od początku odmiennie interpretowany był przez władze w Belgradzie, co ostatecznie stało się istotnym czynnikiem rozpadu Jugosławii?

W 1980 roku, po śmierci Josipa Broz Tito, rząd podjął próby umacniania centralizacji kraju. W odniesieniu do Stowenii A. Erjavec wspomina o

„nastrojach rewolucyjnych: socjalizm samorządowy miał się stać pochodnią nowego porządku społecznego przewyższającego dotychczasowe idee. (...) Nieustannym zapewnieniom o wolności samorządów oraz tajnemu zbrojeniu Jugosławii towarzyszyła w Słowenii promocja kultury jako nośnika Słoweńskiej tożsamości narodowej. Nie wspierano jednak ani kultury wysokiej aglomeracji miejskich, ani kultury alternatywnej młodych intelektualistów, lecz amatorską kulturę «miłośników kultury». (...) Jasno więc widać, że mimo swego intelektualizmu, kosmopolityzmu i postępowości - kultura ta w okresie socjalizmu kontynuowała tradycje burżuazji"8.

W takich okolicznościach geopolitycznych zawiązała się grupa Laibach, a później kolektyw Neue Slowenische Kunst.

\section{KULTURA W JUGOStAWII}

Konflikt z Moskwą uchronił Jugosławię przed intensyfikacją reżimu stalinowskiego, szczególnie silnie odczuwanego w krajach bloku socjalistycznego po 1948 roku. „Jugosławia zerwała ze Stalinem i jej los zależał od otwarcia się na Zachód. Musiała dowieść światu, że szanuje wolność myśli, a do tego celu najlepiej nadawali się artyści zainteresowani zachodnimi trendami"9. Choć mieszkańcy tego kraju byli w lepszej sytuacji niż pozostałe narodowości w bloku, wszelka krytyka systemu miała małe poparcie społeczne, a przeciwnicy realnego socjalizmu byli tępieni przez milicję.

Przed II wojną światową na poszczególnych obszarach Jugosławii dominowały odmienne tendencje artystyczne, które kontynuowano po wojnie. Pojawiły się również nowe - w Zagrzebiu neokonstruktywizm i neoawangarda, w Belgradzie abstrakcja niegeometryczna, w Lublanie, podobnie jak w Nowym Sadzie, konceptualizm i body art. Charakterystyczne dla tego okresu było łączenie się artystów w grupy. Powstały wówczas

\section{$\cdots \cdots$}

A. Erjavec, Neue..., op. cit., s. 104

J. Gow, C. Carmichael, Slovenia and the Slovenes. The Small State and the New Europe, London 2010, s. 52-57.

8 Op. cit., s. 110

9 Op. cit., s. 104. 
między innymi EXAT 51 i Gorgona w Zagrzebiu, OHO w Lublanie, a w Belgradzie Ekipa $A^{3}$ czy grupa związana z Centrum Kultury Studenckiej ${ }^{10}$ przy Akademii Sztuk Pięknych, która zrzeszała takich artystów jak Marina Abramović czy Slobodan Milivojević11. Rozwijane głównie w Belgradzie malarstwo abstrakcji niegeometrycznej było alternatywą dla tendencji neokonstruktywistycznych, których ośrodkiem był Zagrzeb. Stanowiło to, jak sugeruje Piotr Piotrowski, odbicie rywalizacji pomiędzy Chorwacją a Serbią, w tych dwóch ośrodkach bowiem kształtował się charakter artystyczny Jugosławii12.

Warto podkreślić istnienie założonej w 1959 roku Gorgony zmierzającej w stronę krytyki obrazu i dalej, do jego eliminacji. Idąc tym tropem, jeszcze przed 1966 rokiem Josip Vaništa przedstawił projekt wystawy pozbawionej prezentacji prac i składającej się jedynie z samych opisów dzieł, co stanowiło pierwszy w Europie Środkowo-Wschodniej przejaw sztuki konceptualnej. Za pierwszą zrealizowaną wystawę tej sztuki na świecie uznaje się propozycję Setha Siegelauba, która miała miejsce w Nowym Jorku w 1969 roku i składała się z prac istniejących wyłącznie $w$ katalogu ${ }^{13}$. Sztuka konceptualna cieszyła się dużym zainteresowaniem ze względu na łatwość jej rozpowszechniania oraz niski nakład finansowy konieczny do jej produkcji, a używanie języka angielskiego podczas działań lokalnych, dawało poczucie uczestnictwa w nurcie międzynarodowym. O popularności ruchu konceptualnego decydowat jednak przede wszystkim fakt, iż umożliwiał on krytykę władzy ${ }^{14}$. W 1966 roku w stoweńskim Kranju powstała konceptualna grupa OHO. Skupieni w niej artyści, poruszając się na pograniczu literatury (poezji konkretnej) i sztuk wizualnych, korzystali z doświadczeń futuryzmu, dadaizmu oraz pop-artu, odżegnując się od koncepcji sztuki zaangażowanej. Grupa zakończyła działalność w 1971 roku.

W latach siedemdziesiątych Jugosławia pod wieloma względami przypominała kraj zachodnioeuropejski. Pojawiało się tam wielu zachodnich artystów i krytyków, którzy nawiązywali kontakty z artystami jugosłowiańskimi, i vice versa ${ }^{15}$, podczas gdy kontakty z Jugosławią przez rządy pozostałych krajów socjalistycznych były traktowane dość podejrzliwie, nota bene z wzajemnością. "Takie poglądy były w Słowenii na porządku dziennym, chociaż inne regiony Jugosławii utrzymywały kontakty z państwami bloku z powodu wspólnej historii lub granic"16. W Słowenii natomiast szczególnie lata 60. charakteryzowały się niezwykle liberalnym podejściem do kwestii otwarcia granic z Włochami i Austrią. Sytuacja ta nie pozostała bez wpływu na świadomość Słoweńców, postrzegających standard życia w krajach Zachodu za należyty i pożądany ${ }^{17}$.

Jugosławia lat 70. to kraj, w którym, obserwuje się „procesy zazębiania się struktur posttotalitarnego społeczeństwa z konsumpcyjnymi systemami wartości, produkującymi tym samym modele konformistycznego zachowania"18, lecz to także środowisko aktywne artystycznie, wykazujące zainteresowanie awangardą, co implikowało tworzenie się wielu ośrodków wystawienniczych i galerii19. Sytuacja ekonomiczna pozwoliła na inwestowanie w kulturę, a artyści dość dobrze orientowali się we współczesnych trendach sztuki światowej.

10 Temat fenomenu tworzenia się studenckich ośrodków kultury w Jugosławii i ich zadań oraz związanej z nimi Nowej Praktyki Artystycznej został omówiony przez Stefana Vukovicia i Ane Janevski w referacie przedstawionym na SEMINARIUM "1968-1989”, Muzeum Sztuki Nowoczesnej w Warszawie, 28-30 lipca 2008, "Muzeum" nr 6 (4/08), s. 6.

1 P. Piotrowski, Awangarda w cieniu Jatty, Poznań 2005, s. 329-330.

12 Op. cit., s. 113.

13 Op. cit., s. 188-190.

14 Op. cit., s. 349

15 Op. cit., s. 264-265

16 A. Erjavec, Neue..., op. cit., s. 106.

17 J. Gow, C. Carmichael, op. cit., s. 10.

18 P. Piotrowski, op. cit., s. 328.

19 Op. cit., s. 329. 
Rok 1980 stanowił istotny moment w historii federacji. Śmierć Tito zbiegła się ze stopniowym upadkiem dotychczasowego porządku, szczególnie w Europie Wschodniej. Jak wskazuje P. Piotrowski, ciekawe zjawiska obserwowano zwłaszcza w środowisku sztuki krytycznej, jako przykład wskazując Mladena Stilinovića desemantyzującego symbole jako formy "wolne od terroru przeszłości”, aczkolwiek „każda taka estetyzacja (...) w gruncie rzeczy miała charakter ideologiczny" ${ }^{20}$. Pojawiły się wówczas inspiracje radzieckim konstruktywizmem, suprematyzmem Malewicza oraz cytaty z wczesnego okresu realizmu socjalistycznego nawiązujące do awangardy lat $30^{21}$.

Ponieważ w Jugosławii nie istniała oficjalna krytyka władzy, rolę opozycji przejęły środowiska kulturalne kształtujące się w latach 80., takie jak Neue Slowenische Kunst, który podjął strategię nie tyle krytykowania, ile analizy funkcjonowania języka władzy.

„Syndrom słoweński polegał na tym, że republika ta, z jednej strony, cieszyła się w tym czasie względnie większą swobodą polityczną, z drugiej zaś środowiska alternatywne były tu szczególnie aktywne oraz intelektualnie i artystycznie płodne. Co więcej, tworzyły one wręcz ramię aktywności, która stanowiła substytut niezależnego życia politycznego"22.

W Słowenii, charakteryzującej się homogenicznością kulturową, narodowościową i językową, a także bliskością biennale weneckiego i docierającymi z Włoch ideami transawangardy, w latach 80. powstał szczególny rodzaj postmodernizmu, który wykorzystał i zastosował postmodernistyczne techniki dla analizy lokalnego kontekstu ${ }^{23}$. Według A. Erjavca jest to szczególny rodzaj postmodernizmu, którego cechą jest używanie właściwych mu technik i procedur, ale uzupełnionych jawną politycznością i odniesieniami do awangardowej przeszłości. W Jugosławii postmodernizm i postnowoczesność nie oznaczały nadejścia społeczeństwa postindustrialnego, ale upadek socjalizmu, były więc lepiej niż na Zachodzie przyjmowane jako obietnica tego, co miało nadejść po socjalizmie. Zjawiska te pokazywały, że możliwe jest połączenie walki politycznej z oddziaływaniem estetycznym²4.

Wzrost kultury alternatywnej w latach 80. szczególnie wyraźnie obserwowany był W, „najbardziej spośród europejskich miast zainfekowanej postmodernizmem”25, Lublanie. Omówiona niżej propozycja artystyczna Neue Slowenische Kunst z pewnością była konsekwencją fuzji kultury alternatywnej z postmodernizmem. Poprzez odwołanie się w sposób niejednoznaczny do stoweńskich symboli narodowych okazała się kłopotliwa w odbiorze, choć zdaniem artystów NSK, doskonale definiowała kwintesencję słoweńskości.

\section{GRUPA LAIBACH}

W latach 80. po raz pierwszy ekspresja kulturalna narodzona w Słowenii wyszła poza granice obszaru słoweńskojęzycznego i stało się to dzięki awangardowemu i alternatywnemu wymiarowi kultury narodowej26.

20 Op. cit., s. 469. Podobne założenie znajdziemy w działaniach Laibach i NSK.

21 Op. cit., s. 467.

22 Op. cit., s. 469-470

23 A. Erjavec, Przednia i wsteczna straż: awangarda i retro awangarda, (w:) Studia kulturoznawcze. Awangarda w perspektywie postmodernizmu, (red.) G. Dziamski, Fundacja Humaniora, Poznań 1996, s. 39-48.

24 Ibidem.

25 J. Gow, C. Carmichael, op. cit., s. 93

26 Op. cit., s. 90. 
W 1980 roku powstał zespół muzyczny Laibach, który cztery lata później stał się głównym filarem kolektywu Neue Slowenische Kunst. Został zawiązany między innymi z inicjatywy Dejana Kneza i Tomaža Hostnika ${ }^{27}$. Celem pierwszego multimedialnego projektu artystycznego grupy w 1980 roku „Rdeči Revirji” 28 , miało być „obudzenie Czerwonych Dzielnic, które wtedy były uśpione, zatrute i przepełnione socrealizmem i prowincjonalizmem" 29 . Mimo iż wydarzenie zostało zakazane przed jego rozpoczęciem "na podstawie zarzutu o niewłaściwym zastosowaniu symboli"30, artystom udało się oplakatować miasto, a treść i forma plakatów wzbudziły oburzenie i wywołały liczne dyskusje. Socjalistyczna organizacja młodzieży słoweńskiej oskarżyła Laibach o „poniżenie pracy, twórczego ducha i przeszłości”, podkreślając, że nie wszystko "można nakleić na ścianie pod przykrywką słowa punk" 31 . Główny element prowokacji dotyczył jednak nazwy grupy. Laibach to niemiecka nazwa słoweńskiej stolicy, używana w czasie dominacji Habsburgów oraz podczas nazistowskiej okupacji. W Jugosławii, „państwie założonym na zmitologizowanym fundamencie partyzanta oporu wobec faszystowskiej okupacji" ${ }^{32}$, umieszczenie jej w miejscu publicznym w roku śmierci Jozefa Broz Tito, zostało odebrane jak wyszukana prowokacja.

A. Erjavec zauważa, iż od samego początku utworzenia projektu wspólnego organizmu państwowego przez południowych Słowian w 1918 roku,

„tożsamość narodowa i rola Słowenii budziła sporo kontrowersji. Na przestrzeni wieków głównym wrogiem Słoweńców byli Niemcy, dlatego też słoweńscy intelektualiści przyjęli postawę obronną wobec kultury niemieckiej. Po przyłączeniu się do Jugosławii, miejsce Niemiec zajęła kultura serbska lub, szerzej, «jugosłowiańska». Upływ czasu oraz zmiana sytuacji politycznej kraju spowodowały, iż Słoweńcy spojrzeli na swego odwiecznego wroga - kulturę niemiecką - łaskawszym okiem. Tymczasem w Słowenii zaczęły zaznaczać się wpływy kultury serbskiej, która w latach 70. i 80. aspirowała do miana wspólnej kultury jugosłowiańskiej"33.

Był to okres, w którym z jednej strony narastała świadomość, iż system polityczny zmierza ku totalitaryzmowi, z drugiej jednak, wobec pozornej tolerancji wykazywanej przez rząd, nie było powodów do otwartego sprzeciwu politycznego, świadomość ta nie mogła więc znaleźć właściwych form wyrazu. Laibach zaproponował nowy rodzaj krytyki poprzez naśladowanie. Cytował poglądy Hitlera i Goebbelsa, prowokując tym samym elite kulturalną do występowania w obronie wolności artystycznej ${ }^{34}$. Zdaniem Slavoja Žižka:

„W okresie rozpadu socjalizmu w Stowenii Laibach prezentował agresywną, chaotyczną mieszanke stalinizmu, nazizmu i ideologii Blut und Boden. W pierwszym odruchu oświeceni krytycy lewicowi uznali ją za ironiczną imitację rytuatów totalitarnych, jednak akceptacji wobec działań zespołu nieodłącznie towarzyszył niepokój: «A jeśli naprawdę $w$ to wierzą? Jeśli naprawdę utożsamiają się z rytuałem totalitarnym?» (...) Najdoskonalszym fortelem Laibach jest śmiała manipulacja przekazem: publiczność zespołu, [a szczególnie intelektualiści] (...) zadają pytanie [jakie właściwie stanowisko Laibach zajmuje? popiera totalitaryzm, czy nie?] i czekają na odpowiedź, nie zauważając, że Laibach nie funkcjonuje jako odpowiedź, lecz jako pytanie"35.

27 T. Kermanauer, X+[-]11=?, (w:) Ausstelung Laibach Kunst Rekapitulacja/Recapitulation 2009, Katalog wystawy Łódź 2009, s. 40 i 48.

28 Czerwone Dzielnice to okręg przemystowy, do którego, oprócz Trbovlje, należały także Hrastnik i Zagorje ob Savi.

29 M-Maschine. Salto Morale. 2008. Dostępny w internecie: http://saltomorale.blogspot.com/.

30 Laibach 1980-2009, (w:) Ausstelung Laibach Kunst Rekapitulacja/Recapitulation 2009, Katalog wystawy Łódź 2009, s. 186.

31 A. Erjavec, Neue..., op. cit., s. 106.

32 M. Benson, Neue Slowenische Kunst: The "State in Time”, Kineticon Pictures, Text: Art/Politics/Film. 1996. Dostępny w internecie: http://www.kinetikonpictures.com/films/state.htm.

33 A. Erjavec, Neue..., op. cit., s. 104.

34 A. Erjavec, Przednia..., s. 39-48.

35 S. Žižek, Dlaczego Laibach i NSK nie można nazwać faszystami?, (w:) Ausstelung Laibach Kunst Rekapitulacja/Recapitulation 2009, Katalog wystawy Łódź 2009, s. 94. 
Poszukując relacji pomiędzy sztuką i ideologią, grupa początkowo realizowała się także w działaniach plastycznych. Tworzone przez artystów obrazy były częścią kapitału, jaki wnieśli oni w założony później kolektyw, kiedy wizualna tradycja Laibach została przejęta przez grupę Irwin.

W 1982 roku muzycy wzięli udział w festiwalu Novi Rock w stolicy Słowenii, i swoim wystąpieniem zdominowali to wydarzenie. Jak wspomina jego uczestniczka, Eda Čufer ${ }^{36}$ :

„Pamiętam scenę, na której królował pierwszy frontman Laibach, Tomaž Hostnik, naśladujący i parodiujący faszystowskiego dyktatora Włoch, Benito Mussoliniego. Hostnik naśladował zarówno jego wygląd, jak i sposób mówienia. Zaczął, zwracając się do publiczności: "Cari amici Soldati» (...) i mówił dalej w tym samym oratorsko agresywnym stylu, ale w pewnym momencie zmienił głos i od tekstu Mussoliniego przeszedł do recytacji fragmentu konstytucji Jugosławii. Pamiętam nieznośną mieszaninę wszystkich tych przerażających znaków i znaczeń, zderzonych z atmosferą tłumu i efektem słów, wypowiadanych przez Hostnika wzburzonym barytonem, wyliczającym prawa obywateli, jak gdyby wyliczał nasze grzechy czy winy, a nie wymieniał normy prawne, przekazujące władzę w nasze ręce. Trudno powiedzieć, czy publiczności występ się podobał, czy nie, ale dla niektórych z nas była to jakaś wstrząsająca iluminacja albo przełom" ${ }^{\prime 3}$.

Lider zespołu, Tomaž Hostnik, w grudniu 1982 roku popełnił samobójstwo, wieszając się na kozelcu, drewnianej konstrukcji do suszenia słomy - symbolu wsi słoweńskiej38.

W roku 1983 Laibach otrzymał zaproszenie do wzięcia udziału w politycznym programie informacyjnym, w którym muzycy zaprezentowali się w mundurach przypominających nazistowskie i z białymi opaskami oznaczonymi czarnym krzyżem na rękawach. Przedstawiciel grupy „odczytywał przygotowane zawczasu odpowiedzi złowieszczym głosem, podczas gdy pozostali artyści w milczeniu przybierali rozmaite pozy w katastroficznie przystrojonym studio, poobwieszanym plakatami Laibach"39. Grupa podkreślała swoją apolityczność, a „Rdečji Revirji” określiła jako „test na czujność i efektywność działania władz bezpieczeństwa państwowego, projekt który miał zakłócić pozytywny stan świadomości i mechanizmy obronne Czerwonych Dzielnic przeciwko najazdowi wywrotowych elementów innych kultur" ${ }^{40}$. Na koniec programu jego sprowokowany gospodarz nazwał swoich gości "wrogami ludu” i zwrócił się do kilkuset tysięcy telewidzów z apelem o zapobieżenie "rozprzestrzenianiu się laibachowskiej zgnilizny" 41 . W efekcie na grupę został nałożony zakaz publicznych występów na terenie Jugosławii pod nazwą Laibach. Dwa lata później jeden z dziennikarzy pisał: „W idiotycznych odpowiedziach tych dzieciaków w mundurach nie padły żadne bezpośrednie odwołania do faszyzmu, lecz po emisji człowiek budził się jakby z niekończącego się koszmaru"42. Do przytaczanego komentarza S. Žižek dodał w 1989 roku, iż „większość prób racjonalizowania czy choćby usprawiedli-

\section{......}

36 Eda Čufer - ur. 1961, dramaturg, kuratorka, autorka wielu esejów i tekstów krytycznych dotyczących teatru, tańca, sztuk wizualnych i polityki. Od 1984 roku współpracuje z NSK przy wielu projektach.

37 E. Čufer, Fortel Laibach: dwie opowieści autorstwa jednego widza, (w:) Ausstelung Laibach Kunst Rekapitulacja/Recapitulation 2009, Katalog wystawy Łódź 2009, s. 137.

38 Igor Vidmar - znany i ceniony dziennikarz, propagator muzyki rockowej, producent muzyczny i aktywista polityczny. Wypromował wiele grup i artystów, zwłaszcza z nurtu muzyki punk. Prowadzit jedyne niezależne studenckie radio w Jugosławii, Radio študent, powstate w Lublanie w 1969 roku. Był inicjatorem i propagatorem festiwalu Novi Rock w Lublanie. W 1982 roku zorganizował koncert solidarności z opozycją w Polsce przeciw posunięciom Wojciecha Jaruzelskiego] w swoim radiowym programie nadawał audycję „Smrt Tomaža Hostnik”, podczas której odczytał „Apologija Laibach" pozostawioną przez Hostnika jako list pożegnalny (źródło: M-Maschine. Salto Morale. 2008. Dostępny w internecie: http://saltomorale.blogspot. com/2009/12/tomaz-hostnik.html).

39 E. Čufer, op. cit., s. 138

40 Ibidem.

41 Ibidem

42 S. Žižek, List z daleka, (w:) Ausstelung Laibach Kunst Rekapitulacja/Recapitulation 2009, Katalog wystawy Łódź 2009, s. 98. 
wiania działań zespołu i całej NSK w naszym kraju nie trafia przecież w sedno: nie wyjaśnia dostatecznie, skąd bierze się odczucie «niekończącego się koszmaru», o którym pisał dziennikarz" 43 .

W ramach trasy koncertowej Occupied Europe Tour muzycy zawitali również do Polski. Wiktor Skok przytacza słynny incydent z tej wizyty, mający miejsce na konferencji prasowej w Warszawie:

„Gdy Laibach publicznie ogłosili się komunistami, jeden z gości, z uśmiechem na twarzy, wręczył grupie prezent - owinięty w oficjalny organ PZPR «Trybunę Ludu», jeszcze ciepły, fekalny podarek. Laibach odwołał się do postaci generała Jaruzelskiego, a jego słowa potraktowat jako ideologiczny ready made. Ten zabieg, jak i użycie mundurów armii jugosłowiańskiej, przywołuje głębokie kontrowersje jakie stwarzało u ówczesnej subkulturowej, antypaństwowej publiczności użycie znienawidzonej, oficjalnej symboliki"44.

Podobne reakcje Laibach wzbudził w Czechosłowacji, czego rezultatem było odwołanie koncertów w tym kraju.

NEUE SLOWENISCHE KUNST

W październiku 1984 roku, w związku z oficjalnym zakazem występów w Jugosławii oraz jako część strategii rozprzestrzeniania estetyki i filozofii grupy na inne media, Laibach we współpracy z dwiema innymi komórkami powołał Neue Slowenische Kunst. Jak określit to Michael Benson, kolektyw zaczynał swoją aktywność artystyczną jako zbiór teorii wymyślonych przez grupę rockową z zacięciem do prowokacji, chęcią obnażenia pewnych niewygodnych prawd historycznych i absolutnie bez żadnej wiedzy o tym, jak grać na instrumentach muzycznych ${ }^{45}$. "Laibach od początku zajmował w niej [NSK] uprzywilejowaną, kluczową pozycję, wystawiając się tym samym na krytykę ze strony polityków i opinii publicznej. Od samego początku członkowie zespołu występowali anonimowo. Wyznaczali jednego spośród siebie jako rzecznika, a na wywiady odpowiadali w formie pisemnej"46. Pozostałe grupy tworzące kolektyw to formacja teatralna Gledališče Sester Scipion Nasice oraz artyści wizualni - Irwin. Każda z nich pracowała zgodnie z wewnętrzną logiką, regułami i zasadami, jednocześnie pozostawały ze sobą połączone kontekstowo i formalnie. Ich członkowie spotykali się regularnie, by dyskutować i tworzyć plany najważniejszych wspólnych kampanii. Jednym z założeń NSK było wykorzystywanie różnego typu symboli religijnych, faszystowskich lub należących do kultury realnego socjalizmu i tworzenia z nich swoistych kolaży. Wykorzystywano przy tym elementy nachalnej propagandy i kiczu, często na granicy politycznego skandalu, czego celem miała być demaskacja popkultury oraz zerwanie z istniejącymi tabu w sztuce i kontestacja totalitarnego państwa jugosłowiańskiego. Nawiązywano do manifestu grupy Laibach z 1983 roku7, w którym artyści zdefiniowali termin „totalitaryzm” jako cechę nie wyłącznie polityczną, ale dotyczącą wszystkich sfer życia, także kultury, jak również ogłosili, iż aby uniknąć by-

43 Ibidem.

44 W. Skok, Ausstelung Laibach Kunst Rekapitulacja/Recapitulation 2009, Katalog wystawy Łódź 2009 , s. 5.

45 M. Benson, Neue Slowenische Kunst: The "State in Time", Kineticon Pictures, Text: Art/Politics/Film. 1996. Dostępny w internecie: http://www.kinetikonpictures.com/films/state.htm.

46 A. Erjavec, Neue..., s. 108.

47 Opublikowany w numerze 13/14 z 1983 roku. „Nova revija” (od 1981) była „platformą dla kadr antyleninowych, inspirowaną zarówno przez polski ruch "Solidarność», jak i spadkobierców polityki Kavčicia" - zob. J. Gow, C. Carmichael, op. cit., s. 94. 
cia ofiarą manipulacji, sami będą używać jej języka, nadutożsamiając się z władzą ${ }^{48}$. Nie była to więc kontestacja ustroju w sposób bezpośredni.

"Można by rzec, iż uprawiali oni "absurdalny teatr fascynacji władzą", a absurdalność tegoż teatru wydawać by się mogła iście Gombrowiczowska. Działalność NSK nie polegała jedynie na parodiowaniu totalitaryzmu, zresztą określenie "parodiowanie» w kontekście działalności NSK wydaje się być mocno nieprecyzyjne" 49 .

Gledališče Sester Scipion Nasice, grupa teatralna powołana przez reżysera Dragana Živadinova, Edę Čufer oraz Mirana Mohara w 1983 roku, kontynuowała tradycje eksperymentów awangardowych obecnych w teatrze stoweńskim od lat 50. XX wieku, często niepozbawionych elementów krytyki politycznej ${ }^{50}$. Rodzaj manifestu, „Pierwszy List Siostrzany z lat 1983-84 deklarował: "Teatr nie jest pustą przestrzenią. Teatr jest Państwem». (...) Grupa zastrzegła brak stałej sceny i chęć zjednoczenia wszystkich instytucji teatralnych kraju"51. W ramach założonego rok później kolektywu, członkowie, podobnie jak w przypadku Laibach, pozostali anonimowi, a skład osobowy zmieniał się w zależności od przedstawienia, gdyż aktorzy pochodzili z różnych teatrów. W latach 1985-86 wyreżyserowali kilka kultowych przedstawień, między innymi „Krst pod Triglavem”, będący „najlepszą ilustracją metody NSK-retrogardy, która oparta jest na przekonaniu, że traumy z przeszłości mają wpływ na teraźniejszość i przyszłość, a rozwiązanie znajduje się w powrocie do pierwotnego konfliktu"52. Po rozwiązaniu Gledališče Sester Scipion Nasice, Dragan Živadinov powołał Red Pilot Cosmokinetic Theatre, a w 1990 roku Gabinet Noordung Cosmokinetic. W 1995 roku reżyser poświęcił się między innymi zaplanowanemu na pięćdziesiąt lat projektowi Noordung, nazwanemu tak na cześć słoweńskiego badacza przestrzeni kosmicznej, Hermana Potočnika Noordunga.

Również w 1983 roku została założona grupa wywodząca się z lublańskiej sceny graffiti i punkowej, Rrose Irwin Selavy ${ }^{53}$, która weszła w skład NSK, zmieniając swoją nazwę na Irwin. Jej aktywność od początku charakteryzowała się kolektywizmem, a także, zgodnie z fundamentalną procedurą pracy NSK - koncepcją retroawangardy, polegającą na "wykorzystywaniu i odnoszeniu się do powstałych dzieł, przeszłych trendów i idei w sposób bezładny, lecz z wyraźnym celem promowania kultury słoweńskiej"54. Prace grupy Irwin odczytywać można zarówno na poziomie artystycznym, ideologicznym, jak i religijnym. Odwoływały się do totalitarnej symboliki faszyzmu i komunizmu, wykorzystywały symbole politycznej propagandy, realizmu socjalistycznego, sztuki ludowej i religijnej, kicz i elementy zaczerpnięte z historii sztuki ${ }^{55}$, umieszczając je w nowym, zwykle zdecydowanie słoweńskim kontekście, „W czym zbliżali się do włoskiej transawangardy i jej niemieckiego odpowiednika"56. Od momentu powstania Irwin nawiązywał do społecznych problemów Słowenii, dotykał politycznego tabu, przekraczał granice pomiędzy sztuką, praktyką

\section{$\cdots \cdots \cdots$}

4810 przedmiotów przymierza, (w:) Ausstelung Laibach Kunst Rekapitulacja/Recapitulation 2009, Katalog wystawy Łódź 2009, s. 11.

49 Cockney, LAIBACH IRWIN NSK. Kaos ex Machina, 2006-2007. Dostępny w internecie: http://www.kaos-exmachina.pl/magazyn/artykuly/laibach.htm http://www.kaos-ex-machina.pl/magazyn/artykuly/laibach.htm.

50 J. Gow, C. Carmichael, op. cit., s. 92.

51 A. Erjavec, Neue..., op. cit., s. 112.

52 Laibach 1980-2009, op. cit., s. 186

53 Nazwą odwoływała się bezpośrednio do Marcela Duchampa, który wcielał się w postać Rrose Selavy, swojego damskiego alter ego. Tym imieniem podpisywał także niektóre swoje prace. Po raz pierwszy Marcel Duchamp pojawit się jako Rrose Selavy w 1921 roku przed obiektywem aparatu fotografa amerykańskiego Man Raya.

54 A. Erjavec, Neue..., op. cit., s. 112

55 M. Ślizińska, IRWIN (Stowenia), TRZY PROJEKTY malarstwo, instalacje, performance, Centrum Sztuki Współczesnej, Zamek Ujazdowski, Galeria 2 8.12.98-17.01.99. Dostępny w internecie: http://csw.art.pl/ new/98/irwin.html.

56 Ibidem. 
i życiem. Motto grupy, „Was ist Kunst”, można zinterpretować jako wyraz poszukiwania własnej tożsamości w subkulturze lat 80. Współpracując z NSK, artyści nie prezentowali sztuki zaangażowanej wprost, lecz budowali krytyczną strategię „denaturalizacji” kultury socjalistycznej, jej rytuałów i znaków, dekonstruując komunistyczną "politykę widzenia" (...), co polegało „na skrajnym nadutożsamieniu z ideologią komunistyczną"57. Irwin postawił sobie za cel przeanalizowanie estetycznej sfery ideologii, uważając takie działania za najskuteczniejszą metodę odkrycia niejawnej podstawy „dającej możliwość cynicznego czerpania korzyści z ideologii, bez której żaden system nie może funkcjonować" 58 .

Novi Kolektivizem to sekcja powołana w celu wykonywania projektów graficznych na potrzeby zadań i wizerunku organizacji. Prowadzona przez projektanta Darko Pokorna, składała się z członków każdej z głównych grup NSK. Ta niezwykle aktywna komórka była odpowiedzialna za projekty plakatów, książek, paszportów (po 1991 roku) i papieru firmowego, dokumentację oraz nadzór nad budową strony internetowej. Projektem dla grupy Laibach zdobyła nagrodę w 1994 na Biennale Wzornictwa Przemysłowego w Lublanie. Novi Kolektivizem wykonywał także zlecenia zewnętrzne, np. dla Muzeum Sztuki Nowoczesnej w Lublanie czy dla Radia i Telewizji Słowenii. Do roku 1987 grupa była raczej na uboczu, pełniąc funkcję wspierającą działania NSK. Wtedy to za sprawą osławionego zwycięstwa w konkursie na plakat z okazji Dnia Młodzieży zyskała rozgłos, a zaraz potem wywołała skandal, kiedy projekt okazał się bliźniaczo podobny do nazistowskiego obrazu Richarda Kleina „Trzecia Rzesza" z 1936 roku. Członkowie NK tak wyjaśniali swoje postępowanie:

„Plakat na Dzień Młodzieży na zawsze wymazał negatywną symbolikę mrocznej przeszłości. Swastykę przykryła pięcioramienna gwiazda i niebiesko-biało-czerwona flaga Jugosławii - tak, jak [jugostowiańska] partyzantka pod osłoną nocy przekreślała faszystowskie symbole znakiem czerwonej gwiazdy. Nazistowski herb zastąpiło sześć pochodni sześciu narodów Jugosławii, zaś niemieckiego orła - symbol pokoju: biały gołąb" 59 .

Wykorzystanie nazistowskiego plakatu przez NK było zabiegiem przewrotnym, a jego najwyższa ocena w oczach Komunistycznej Partii Jugosławii, skompromitowała te ostatnią. Artyści stanęli przed sądem, który ich uniewinnił. Nie bez wpływu na taki wyrok miała sytuacja Słowenii w ramach federacji i napięcie polityczne na linii Lublana-Belgrad ${ }^{60}$. Podobnie jak podczas zakazu występów Laibach, kiedy Radio Študent emitowało utwory tej grupy, również w tej sytuacji, NSK uzyskało wsparcie intelektualistów słoweńskich, którzy w ich obronie wystosowali list otwarty do tygodnika Mladina ${ }^{61}$.

ODERWANIE OD PRZESTRZENI

W 1989 roku runął mur berliński, co uważa się za symboliczny koniec podziału Europy. Rok później w Słowenii odbyło się referendum, którego wynik jednoznacznie wskazywał na chęć odłączenia się od Federacyjnej Jugosławii i funkcjonowania jako niepodległe pań-

60 Dokładnie rok później (w maju 1988) doszło do głośnego procesu sądowego tygodnika słoweńskiego "Mladina" o charakterze polityczno-krytycznym, którego historia sięga roku 1920. Tygodnik opublikował „przeciek" jakoby Jugosłowiańska Armia Narodowa zamierzała „przywrócić porządek w Słowenii”. Proces odbywał się za zamkniętymi drzwiami, w języku serbo-chorwackim, mimo iż wszyscy czterej oskarżeni byli Słoweńcami. Fakt ten przez słoweńskich liderów politycznych i opinię publiczną został potraktowany jako atak na tożsamość słoweńską. Por.: J. Gow, C. Carmichael, op. cit., s. 150-154.

61 "Mladina” wspierała działania Neue Slowenische Kunst, gdyż były one spójne z misją tygodnika: przełamywać społeczne tabu różnymi środkami. Por.: J. Gow, C. Carmichael, op. cit., s. 96.
} 
stwo ${ }^{62}$. W 1991 roku, po 10 dniach wojny z armią Jugosłowiańską, po raz pierwszy w historii proklamowano powstanie Republiki Stowenii.

Rok później kolektyw Neue Slowenische Kunst przekształcił się W "NSK State in Time", projekt artystyczny polegający na utworzeniu państwa nieposiadającego fizycznych granic, określanego nie przez kategorię przestrzeni, ale czasu i ruchu ${ }^{63}$. Działanie to stanowiło artystyczny komentarz zarówno wobec przemian zachodzących na mapie Europy, jak i napiętej sytuacji politycznej na terenie Jugosławii. Utworzone wówczas „Państwo w Czasie” to rodzaj eksperymentalnej alternatywy, konceptualnego artefaktu. Każdy, kto podziela idee tego wirtualnego kraju, może zostać jego obywatelem, nabyć paszport i uczestniczyć w realizacjach ambasad otwieranych czasowo w różnych punktach świata oraz brać udział w towarzyszących im wernisażach i dyskusjach. Z okazji trzydziestej rocznicy powstania grupy Laibach, przed dwoma laty w Berlinie odbył się pierwszy Kongres Obywateli NSK. W tym samym roku, na fali popularności paszportu wśród mieszkańców Nigerii, w Lagos zorganizowana została konferencja "Towards a Double Consciousness: NSK Passport Project".

Warto wspomnieć także o jednym z projektów, którego inicjatorem jest Irwin. Artyści ci kontynuują swoją działalność artystyczną, prezentując prace na ekspozycjach indywidualnych w Europie i Stanach Zjednoczonych. Od ponad dekady realizują także wizualne projekty internetowe, czego przykładem jest zapoczątkowany w 2000 roku "East Art Map". Ta inicjatywa, zainspirowana procesami transformacji w Europie po 1989 roku, porusza kwestię hegemonii Zachodu w konstruowaniu historii sztuki. Artyści, początkowo w formie strony internetowej, zaproponowali stworzenie subiektywnej mapy sztuki Europy Wschodniej. Projekt ten, który od formy czysto artystycznej przeewoluował ku naukowości i teorii sztuki współczesnej, wymieniany jest jako jeden z ważniejszych w obszarze badań nad tożsamością (sztuki) Europy Środkowej i Wschodniej. Skutkiem jego rozwoju stała się między innymi organizacja międzynarodowego sympozjum interdyscyplinarnego "Mind the map! - History is not given" w 2006 roku w Lipsku64.

\section{EPILOG}

Słoweński kolektyw Neue Slowenische Kunst stanowił silny akcent rewolucji kulturalnej lat 80. XX wieku i był „pierwszym znaczącym towarem eksportowym” tego kraju. Paradoksalnie, wprowadzit on kulturę słoweńską na arenę międzynarodową, posługując się antytezą narodowej tradycji65.

Ostatnie działania artystów, niegdyś ściśle współpracujących ze sobą w ramach kolektywu, wskazują na rozluźnienie więzi pomiędzy grupami, choć zarówno Laibach, jak i Irwin prowadzą bardzo aktywną działalność artystyczną - koncertową w przypadku pierwszej z wymienionych grup i wystawienniczą w przypadku obu. Niezmiennie kontynuowane

\section{$\cdots \cdots$}

62 A. Erjavec, Neue..., op. cit., s. 105-106.

63 P. Piotrowski, op. cit., s. 473.

64 East Art Map. German Federal Cultural Foundation, 2004. Dostępny w internecie: http://www.eastartmap. org. J. Kowalska w artykule pt. "Znaczenia awangardy" w internetowym "Obiegu" (25.08.2006 aktualizacja 20.03.2009 22:36) wymienia ów projekt jaką jedną z dwóch istniejących, obok Awangardy w cieniu Jałty P. Piotrowskiego, próbe zrekonstruowania historii sztuki współczesnej Europy Wschodniej. Por: Mind the map! History is not given. A critical anthology based on the Symposium, (red.) M. Gržinić, G. Heeg, V. Darian, Leipzig 2006.

65 J. Gow, C. Carmichael, op. cit., s. 100-101. 
są także poszczególne projekty, czemu towarzyszy organizacja spotkań, wystaw i konferencji. Zainicjowane przez artystów działania mają swój oddźwięk w postaci kolejnych publikacji i opracowań naukowych, a niektóre z nich zaczęły rozwijać się niezależnie od ich inicjatorów, będąc głosem w dyskusji na temat kultury współczesnej, sztuki obszaru Europy Środkowej i Wschodniej, rozwoju mediów czy globalizacji. Niniejszy artykut wspomina jedynie dwa z nich, „NSK State in Time” oraz „East Art Map” grupy Irwin, pomija natomiast całkowicie zarówno analizę twórczości Laibach z jej odniesieniami do kultury muzycznej pogranicza germańsko-słowiańskiego, jak i twórczość sceniczną Gledališče Sester Scipion Nasice.

Jak zauważa S. Žižek, obecnie „przestrzeń wyznacza polityczna i ekonomiczna globalizacja oraz jej ideologia, czyli multikulturalizm"66, lecz dodaje, że w omawianej części Europy „funkcjonowanie tych państw wciąż bardziej opiera się na zasadzie modernistycznego nacjonalizmu i «znacjonalizowanej» kultury niż kultury metropolitalnej, postmodernistycznej, postnacjonalistycznej i wieloetnicznej, właśnie multikulturalnej"67. W przypadku aktywności artystów związanych z NSK mamy jednak okazję zaobserwować ewolucję nie tylko działalności artystycznej, lecz także tożsamościowej. Uwzględniając zarówno związek z przestrzenią, jak i zjawisko transmigracji, może ona stanowić ilustrację zmian, stać się ich swoistym barometrem. Jeśli przyjąć za słuszne twierdzenie Marty Bucholc, iż "artysta chwyta intuicyjnie to, co kluczowe w egzystencji otaczającego go społeczeństwa", analiza aktywności tej grupy twórców pozwoli poczynić interesujące obserwacje.

W odniesieniu do historii i rozwoju Stowenii istnieje pogląd, jakoby tak mały kraj, uzyskawszy terytorialną niepodległość w momencie historycznym przełomu wieków, w obliczu gwałtownych przemian współczesności charakteryzujących się ogólną tendencją do zacierania różnic, narażony był na zagubienie własnej tożsamości. Gdyby rzeczywiście ku temu zmierzał, pozostaje mieć nadzieję, iż procedura ta będzie równie czasochłonna jak proces kształtowania się owej tożsamości. Wszak niechętnie pozbywamy się dóbr, w posiadanie których weszliśmy z takim trudem. Nawet jeśli okazywanie tego, jak wielką stanowią wartość, miałoby odbywać się w sposób tak niejednoznaczny jak w przypadku twórców słoweńskiego kolektywu artystycznego Neue Slowenische Kunst.

\section{FROM SPACE TO TRANSMIGRATION. NATIONAL IDENTITY IN THE MIRROR OF THE ARTISTIC CULTURE ON THE EXAMPLE OF COLLECTIVE NEUE SLOWENISCHE KUNST CREATIVITY}

\section{Summary}

"The end of geography" was postulated two decades ago by Richard O'Brien. This article tries to refer it to the Slovenes, the nation which only for two decades has its own state and its own geography. The case study of the artist, the ideal transmigrant, as Marta Bucholc would say, gives us the possibility to understand the nature of the contemporary world in the best way. That is why the object of an analysis in this article is the collective Neue Slowenische Kunst, one of the most important cultural and social phenomena of the1980s in Slovenia.

This article presents very briefly the history of the state of Slovenia and the development of culture of this country, especially in the late 1980s and in the 1990s when very important changes on

66 P. Piotrowski, op. cit., s. 456

67 Op. cit., s. 457. 
the map occurred. As a consequence, NSK's artists decided to detach their projects from space and situate them in time, but it was not a gesture of including themselves in the so-called "global trend." On the contrary, it was a very serious proposition of the revision of their national and artistic, Slovenian and Eastern European, identity.

Slavoj Žižek probably was right that this part of Europe requires a separate study, without automatically entering it into the framework of the ideology of globalization.

Keywords: transmigration, identity, culture, globalization, contemporary art, Eastern Europe, Slovenia, Neue Slowenische Kunst 